\title{
INTRUSIVE RELATIONSHIPS OF GRANITE AND DOLERITE AT LAGUNTA CREEK, FREYCINET PENINSULA
}

\author{
by John L. Everard
}

(with one table, five text-figures and eight plates)

Everard, J.L., 2001 (31:xii): Intrusive relationships of granite and dolerite at Lagunta Creek, Freycinet Peninsula. Pap. Proc. R. Soc. Tasm. 135: 63-74. https://doi.org/10.26749/rstpp.135.63 ISSN 0080-4703. 386 Howden Road, Howden, Tasmania, Australia 7054.

Coastal exposures immediately south of the mouth of Lagunta Creek, Freycinet Peninsula, eastern Tasmania, illustrate the temporal and spatial relationships between various Devonian granites and a dolerite dyke. The oldest granite, an equigranular grey hornblende-biotite adamellite containing abundant mafic enclaves, was intruded by a more felsic, equigranular to variably porphyritic or seriate pink alkali feldspar granite, and associated aplite, leucogranite and pegmatite dykes. Field relationships indicate brittle fracture and stoping of the adamellite during dilational emplacement of the pink granite. Minor bodies of granite porphyry are also younger than the adamellite. A dolerite dyke, of hawaiitic composition and containing plagioclase megacrysts, intrudes the adamellite and also crosscuts the aplite and leucogranite dykes, and is the youngest phase.

The granites are metaluminous to very weakly peraluminous, and are classified as I-types on both mineralogical and geochemical criteria. The adamellite is unfractionated and chemically reduced, and, together with similar rocks at Wineglass Bay and Cape Tourville, constitutes the Bluestone Bay Suite, which is geochemically distinct from, and younger than, other eastern Tasmanian granodiorite/ adamellites. In contrast, both the pink granite and, to a lesser extent, the granite porphyry are fractionated and locally magnetite-bearing. Fractionation has resulted in high $\mathrm{Rb}, \mathrm{Y}, \mathrm{Th}$ and $\mathrm{Pb}$ and low $\mathrm{P}, \mathrm{Sr}$ and $\mathrm{Ba}$. The dolerite dyke, despite its alkalic major element chemistry, is depleted in $\mathrm{Nb}$ like some other granite-associated mafic rocks in the southern Lachlan Fold Belt.

Key Words: granite, dolerite, enclaves, Devonian, Freycinet Peninsula, Tasmania

\section{INTRODUCTION}

There are few studies of the Devonian granites that form most of Freycinet Peninsula (fig. 1), and only the southern tip has been systematically mapped by the Tasmanian Geological Survey (K. D. Corbett, pers. comm.). Theinferred Ordovician-Early Devonian Mathinna Group country rocks occur only as a small area near Bluestone Bay (Cocker 1977). A major north-south trending fault, downthrown to the west, transects the west coast of the Peninsula near Hepburn Point and Weatherhead Point. Jurassic dolerite lies west of the fault, apart from small areas of Triassic sandstone west of Bryans Bay. The fault continues southward to bisect Schouten Island, the eastern half of which is composed of granitic rocks (Bacon \& Corbett 1984).

Foreshore exposures near Coles Bay were examined in detail by Groves (1965), who also produced a sketch map of the Hazards area. He described the dominant rock type as a variably porphyritic "red adamellite", associated with microadamellite and quartz feldspar porphyry dykes and minor pegmatite. This was thought to be younger than an even-grained "grey adamellite with xenoliths", noted in the Bluestone Bay and Wineglass Bay areas.

A more detailed map of the Hazards Range, accompanied by field and petrological descriptions of the various granite types, was provided by Dunderdale (1989). She showed that most (>90\%) of this area consists of "red microcline granite", locally yellow due to hydrothermal alteration, with minor intrusions of quartz feldspar porphyry and microgranite. Small bodies of granodiorite at Wineglass Bay and "white granite" southeast of Fleurieu Point were both shown to be older intrusions.

McDougall \& Leggo (1965) obtained a Rb/Sr age of $375 \mathrm{Ma}$ (now recalculated to $368 \mathrm{Ma}$ using new decay constants) from biotite in a "leucocratic pink granite" from the quarry south of Coles Bay. This was considered a minimum age. K/Ar dates from the same biotite yielded slightly younger ages of 347 to $355( \pm 10) \mathrm{Ma}$ (now 353 to $361 \mathrm{Ma}$ ) which were attributed to resetting. A whole rockmineral $\mathrm{Rb} / \mathrm{Sr}$ isochron gave a younger age of $353 \mathrm{Ma}$ (now $345 \mathrm{Ma}$ ), which was discounted due to the likelihood of mobility of radiogenic $\mathrm{Sr}$ in feldspars.

Cocker (1977) also conducted a $\mathrm{Rb} / \mathrm{Sr}$ study, and provided a simple map, of granite and granodiorite in the Coles Bay-Bluestone Bay area. Probably the most reliable dates (recalculated using new decay constants) are from biotites: $370.8( \pm 3)$ Ma from a pink felsic granite and $372.8( \pm 3)$ Ma from a granodiorite, both from north of Sleepy Bay. The data are consistent with those of McDougall \& Leggo (1965) and suggest that pink felsic granite was intruded shortly after the granodiorite in the late Middle Devonian (Givetian).

This paper describes the excellent coastal exposures of granite which, interrupted by small sandy beaches, extend from Lagunta Creek (at the southern end of Hazards Beach) for $3.5 \mathrm{~km}$ SSW to Cooks Beach. The most varied geology is within $1 \mathrm{~km}$ of Lagunta Creek (fig. 2).

\section{ADAMELLITE/GRANODIORITE}

Theoldestgranite in the area, well exposed as the country rock to the dolerite dyke at the mouth of Lagunta Creek (pl. 1), is a grey to white, medium- to fine- grained (1-3 mm) equigranular and unfoliated adamellite, in which scattered flakes of shiny black to dark green biotite and dull steel-grey hornblende are readily visible in hand specimen. It crops out along the shore southward for about $1 \mathrm{~km}$, but is intruded, in places intensely, by other rock types, as described below.

The adamellite contains conspicuous and numerous (1-2\% of outcrop) dark-grey to grey-green, finer grained $(0.5-2 \mathrm{~mm})$ mafic enclaves (pls 2,3$)$. They are typically 


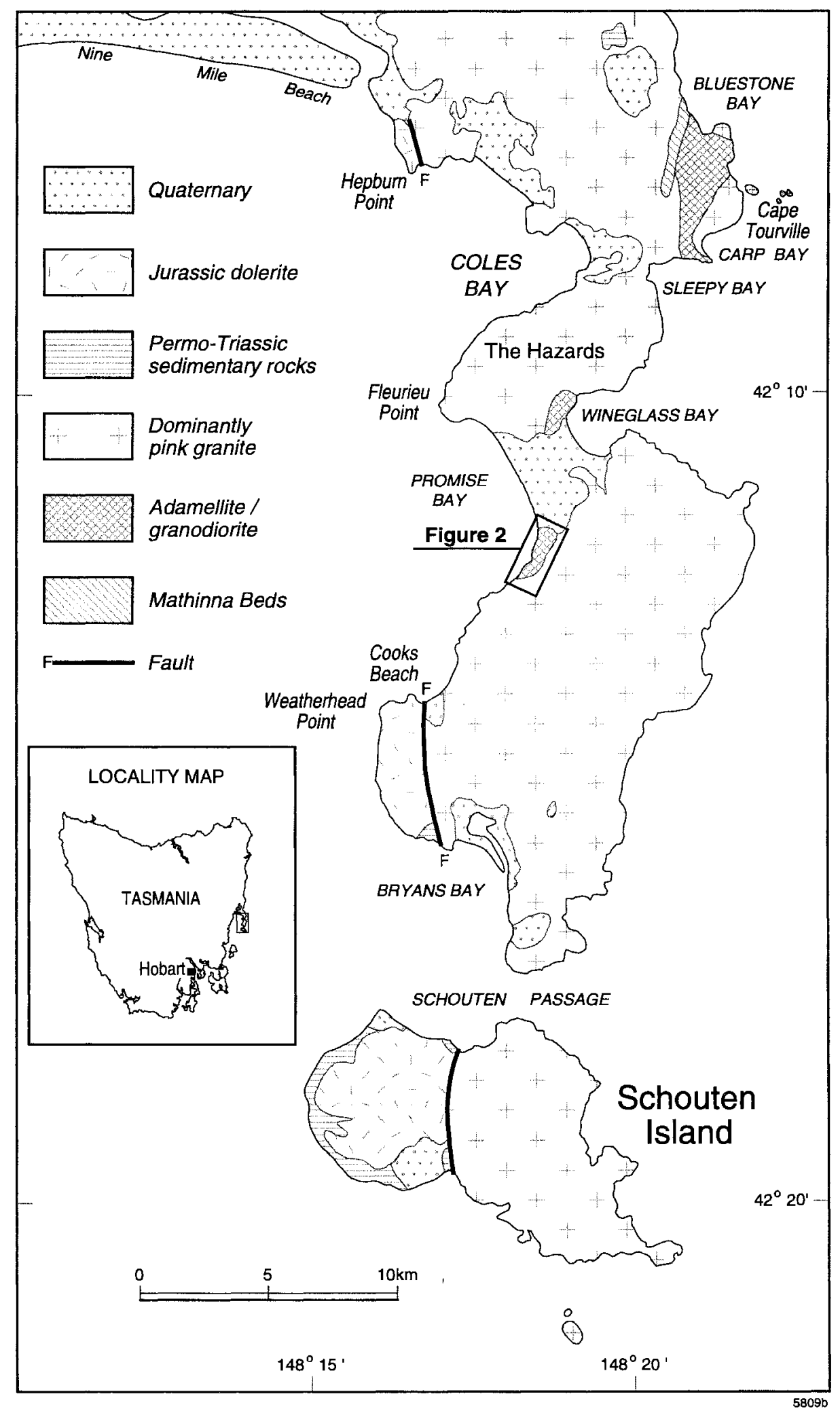

FIG. 1 -- Simplified geology of Freycinet Peninsula (after Forsyth et al. 1995 as modified to 17/8/2001; original sources include Cocker 1977, Bacon \& Corbett 1984, Dunderdale 1989 and K. D. Corbett, pers. comm.).

ellipsoidal in shape and very variable in size, with long dimensions ranging from a few tens of millimetres to commonly $0.4 \mathrm{~m}$ or more. A few are crudely polygonal or irregular in shape (pl. 3), but with generally rounded rather than angular corners. Contacts against the host adamellite are usually quite sharp, but without fine-grained margins, and slightly wavy on a very small scale. Some of the smaller enclaves are coarser-grained, paler (with less biotite) and less mafic. These generally also have more diffuse margins and are texturally transitional to the host adamellite. Many enclaves contain scattered microphenocrysts, oblong to equant polygonal in outline, of dull white feldspar. 


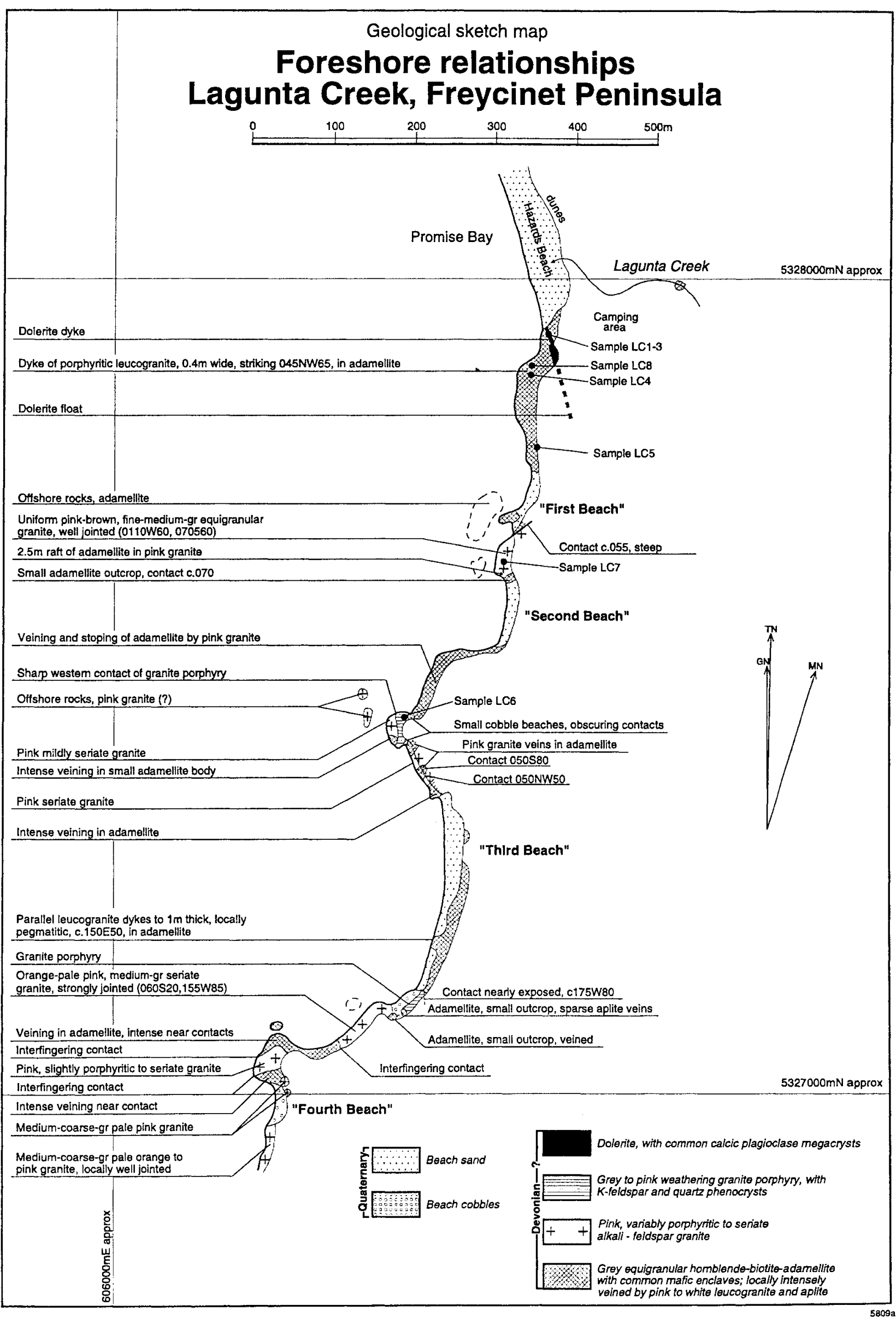

FIG. 2 - Geological sketch map, foreshore relationships south of Lagunta Creek, Freycinet Peninsula. 


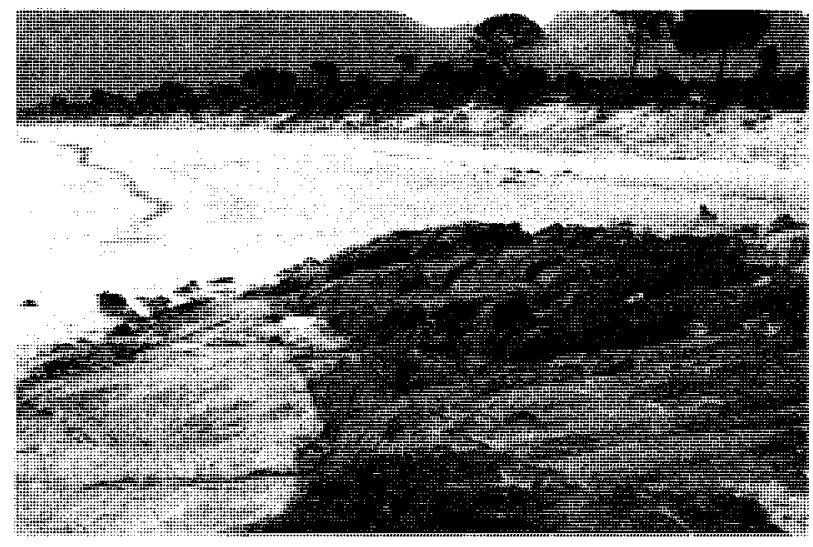

PLATE 1

General view looking north from near the mouth of Lagunta Creek at the southern end of Hazards Beach, showing in foreground the stepped western contact of the dolerite dyke with adamellite.

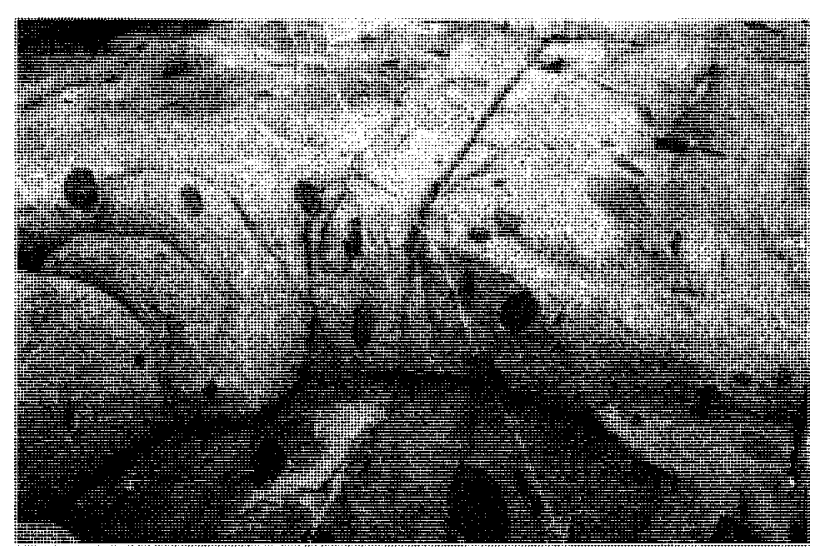

PLATE 2

General view of adamellite, showing numerous, mostly ellipsoidal to irregular enclaves and narrow aplite vein. The diameter of the lens cap is $50 \mathrm{~mm}$.



PLATE 3

Close-up of enclaves within adamellite. The larger enclave is atypical in its crudely polygonal shape. The diameter of the coin is $28 \mathrm{~mm}$

\section{Petrography}

In thin section the adamellite (sample LC4) is seen to consist mainly of quartz, feldspar (plagioclase more abundant than alkali feldspar), biotite and hornblende. Zircon, titanite, allanite, apatite, opaque minerals and chlorite (as an alteration of biotite) are accessory minerals.

Quartz occurs as clear unstrained anhedra, mostly 1$3 \mathrm{~mm}$ across. Plagioclase is typically oblong subhedral (up to $2 \mathrm{~mm}$ long) and in places shows incipient sericitisation. Extinction angles show that it may be as calcic as $\mathrm{An}_{48}$, but concentric zoning is frequently apparent. Potash feldspar (orthoclase) is typically equidimensional and subhedral, and also often strongly and concentrically to irregularly zoned, and partly sericitised. Biotite is pleochroic from very dark brown to pale yellow-brown and is locally partly altered to pale green chlorite. Hornblende (pleochroic with $\alpha$ pale yellow-brown, $\beta$ olive-green, $\chi$ sea-green) occurs as elongate bladed prisms up to $1.5 \mathrm{~mm}$ long and irregular clots up to $2 \mathrm{~mm}$ across, which may enclose cores of sievetextured relict clinopyroxene. Hornblende and biotite are often closely associated and sometimes intergrown. Both minerals occasionally occur as inclusions in quartz, indicating that they crystallised earlier.

Allanite occurs as scattered, rather turbid, isolated equant euhedra, in section polygonal and up to $0.8 \mathrm{~mm}$ across. Typically it is pale orange-brown, weakly pleochroic and only partly metamict but variably altered to paler to colourless secondary minerals. Radiating cracks in enclosing quartz and feldspars, and bent adjacent biotites, are attributed to strain caused by increase in volume during metamictisation. Occasional zircon grains, small apatite rods and rare tiny opaque blebs occur mainly as inclusions in biotite and hornblende. These accessory minerals are considered to be early crystallising, or possibly restite, phases. In contrast, titanite occurs as fine-grained anhedral aggregates and is probably secondary.

The hornblende adamellite (sample LC4) is essentially non-magnetic (susceptibility $0.1-0.2 \times 10^{-3} \mathrm{SI}$ ), and it is a reduced or ilmenite-series granite (Ishihara 1977).

A thin section of a mafic enclave (sample LC5A) shows that it is mineralogically similar to the host adamellite, but is finer-grained (mostly less than $0.5 \mathrm{~mm}$ ), and mafic minerals are more abundant. Hornblende (pleochroic from sea-green to pale yellow-green) occurs with minor biotite (dark brown to pale yellow) in clots several millimetres across. Quartz, plagioclase and orthoclase, together with accessory zircon and apatite, are also present. Opaque phases are very sparse.

Petrographically very similar enclave-bearing equigranular hornblende-biotite adamellite/granodiorites occur at the northern end of Wineglass Bay (sample WGB, AMG reference FP07203115) and near Cape Tourville (sample CTV, FP09503530). The former is slightly more felsic than sample LC4 and apparently lacks relict clinopyroxene, whilst the latter has more extensively altered feldspar.

\section{Geochemistry}

A major element analysis (table 1) of adamellite (sample LC4) shows a relatively mafic $(<70 \%)$, strongly metaluminous (ASI $<1$ ) composition. Calculated pseudomodes suggest that the rock is an adamellite in the modified Streckeisen (1973) classification scheme (fig. 3). Similar rocks from 
Wineglass Bay (sample WGB; sample CD8 of Dunderdale 1989) and the Cape Tourville-Sleepy Bay area (sample CTV; samples TB6 and TB54 from database of B.W. Chappell) plot as slightly more quartz-rich adamellites, transitional to granodiorite.

In detail, sample LC4 is slightly more mafic than the Wineglass Bay and Cape Tourville rocks, with generally lower $\mathrm{SiO}_{2}$ and higher $\mathrm{TiO}_{2}$, total $\mathrm{FeO}, \mathrm{MgO}$ and $\mathrm{CaO}$. On simple two element variation diagrams (e.g. figs $4 \mathrm{~A}-$ D) the available analyses generally plot colinearly, suggesting derivation from a common source, followed by differentiation by variable degrees of separation of entrained restite from the melt (e.g. Chappell \& White 1992). It is proposed that these adamellite/granodiorites be termed the Bluestone Bay Suite.

Petrographically and chemically these rocks are clearly I-rype granites. The low $\mathrm{SiO}_{2}, \mathrm{Rb}(<250 \mathrm{ppm})$ and high $\mathrm{Sr}(>50 \mathrm{ppm})$ and $\mathrm{Ba}(>200 \mathrm{ppm})$ identify them as unfractionated granites, using the criteria of Chappell et al. (1991).

For most elements, the enclave LC5 generally lies near extrapolations of the trends defined by the host granites to more mafic compositions, and on this basis it could represent an aggregate of modified restite (following White \& Chappell 1977, Chen et al. 1989). However, other interpretations are possible. Similar mafic enclaves are found within other relatively mafic granites in eastern Tasmania, eastern Australia and worldwide. Most workers have interpreted them as globules of basaltic magma that were injected into the partly molten granite and incompletely mixed (mingled) with it (e.g. Reid et al. 1983, Vernon 1984), but others regard them as cumulates genetically related to the granite (e.g. Flood \& Shaw 1995).

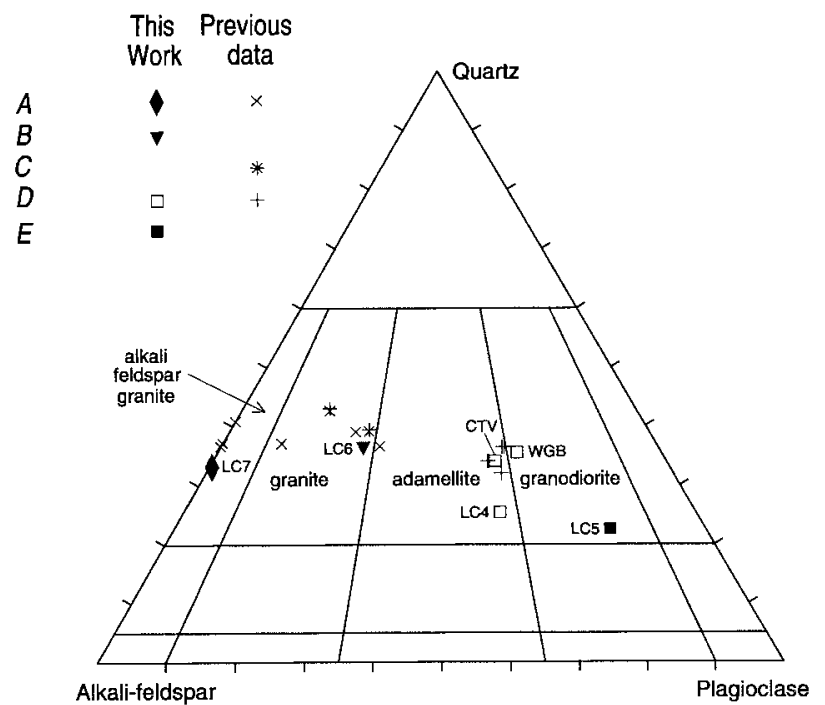

FIG. 3 - Calculated pseudomodes of analysed granitic rocks from Freycinet Peninsula, plotted on the granitoid classification diagram of Streckeisen (1973), modified by the separation of an adamellite (= monzogranite or quartz monzonite of some authors) field from the granite field. (A) Pink alkali feldspar granite and related rocks; $(B)$ granite porphyry; $(C)$ white granite at Fleurieu Point; (D) grey adamellite; $(E)$ enclave in grey adamellite.

\section{Comparison with Other Eastern Tasmanian Granites}

The nearest outcropping adamellite/granodiorites are small coastal exposures on Long Point and Piccaninny Point, some $40-50 \mathrm{~km}$ to the north. These are apparently similar coarse, even-grained to slightly porphyritic, medium-grained, enclave-bearing hornblende-biotite granites (Turner \& Calver 1987: 63-64). However, compared to the Bluestone Bay Suite, the two available analyses (Turner et al. 1986) have distinctly higher $\mathrm{MgO}$ (fig. $4 \mathrm{~A}$ ) and lower $\mathrm{Na}_{2} \mathrm{O}$, $\mathrm{Al}_{2} \mathrm{O}_{3}, \mathrm{Sr}$ (fig. 4C) and Th at equivalent total FeO.

As noted by Turner et al. (1986), the St Marys Porphyry (the partly extrusive equivalent of an I-type granodiorite) and other members of the Scamander Tier Suite are chemically dissimilar to the Long Point/ Piccaninny Point adamellite/granodiorites. The Scamander Tier suite rocks also differ from the Bluestone $\mathrm{Bay}$ Suite, with higher $\mathrm{SiO}_{2}$, $\mathrm{Y}$ (fig. 4D) and $\mathrm{Zr}$ and lower $\mathrm{Al}_{2} \mathrm{O}_{3}, \mathrm{MgO}$ (fig. 4A), $\mathrm{CaO}$ (fig. $4 \mathrm{~B}$ ), $\mathrm{Na}_{2} \mathrm{O}, \mathrm{Sr}$ (fig. $4 \mathrm{C}$ ) and $\mathrm{Th}$ at equivalent total $\mathrm{FeO}$.

In addition, both the $388 \pm 1 \mathrm{Ma} \mathrm{Rb} / \mathrm{Sr}$ emplacement age of the St Marys Porphyry and the similar ages (385$389 \mathrm{Ma}$ ) of the Piccaninny Point adamellite (Turner et al. 1986) are much older than $372.8 \pm 3 \mathrm{Ma} \mathrm{Rb} / \mathrm{Sr}$ age of Cocker (1977) from north of Sleepy Bay.

The small Piccaninny Creek pluton (Turner et al. 1986) near Chain of Lagoons (not to be confused with the body at Piccaninny Point) is also chemically unlike the Bluestone Bay Suite (figs 4A-D).

Further north, the hornblende-bearing granodiorites of the Blue Tier Batholith are unlikely correlates, as there is unequivocal field and isotopic evidence that at least the Gardens and George River granodiorites are still older than the rocks of the Scamander Tier Suite (e.g. McClenaghan et al. 1992).

\section{PINK ALKALI FELDSPAR GRANITE}

About $300 \mathrm{~m}$ south of Lagunta Creek, a few metres to the south of a small sandy beach, a small exposure of enclavebearing adamellite has a probably steep and northeasterly trending contact (not quite exposed) against a much more felsic, pink to red, medium- to fine-grained, equigranular granite. The pink granite is well jointed, very uniform, and lacks aplite veins or enclaves.

About $75 \mathrm{~m}$ further south, at the northern end of a second small sandy beach, there is a contact, striking at about $250^{\circ}$, against a small $(3 \times 3 \mathrm{~m})$ flat outcrop of white enclave-bearing adamellite to the south. Here the pink granite is equigranular to variably porphyritic, locally containing small phenocrysts of potassium feldspar (5$15 \mathrm{~mm})$ and quartz $(\leq 5 \mathrm{~mm})$. Narrow, finer grained leucogranite and aplite dykes occur within it, but unlike those in the adamellite which they otherwise resemble, their margins and terminations are frequently diffuse and indistinct. They appear to be late stage segregations directly derived from the pink granite.

South of the second sandy beach, the enclave-bearing adamellite is intruded by dykes, up to $80 \mathrm{~mm}$ wide, of medium-grained equigranular pink granite. The dykes become wider (up to $1 \mathrm{~m}$ ) and more numerous southward, and form a network throughout the adamellite (pl. 4). Locally they are very coarse-grained to pegmatitic (20- 
TABLE 1

New chemical analyses of Devonian granites and dolerite, Freycinet Peninsula

\begin{tabular}{|c|c|c|c|c|c|c|c|c|}
\hline $\begin{array}{l}\text { Field no. } \\
\text { Reg. no. } \\
\text { Analysis no. } \\
\text { AMG (FP...) } \\
\text { Rock type }\end{array}$ & $\begin{array}{r}\text { LC4 } \\
004439 \\
910750 \\
06512788 \\
\text { adamellite }\end{array}$ & $\begin{array}{r}\text { LC5 } \\
004440 \\
910751 \\
06522780 \\
\text { enclave }\end{array}$ & $\begin{array}{r}\text { WGB } \\
004450 \\
980424 \\
07203115 \\
\text { adamellite }\end{array}$ & $\begin{array}{r}\text { CTV } \\
004451 \\
980423 \\
09503530 \\
\text { adamellite }\end{array}$ & $\begin{array}{r}\text { LC7 } \\
004443 \\
910753 \\
06482765 \\
\text { granite }\end{array}$ & $\begin{array}{r}\text { LC6 } \\
004442 \\
910752 \\
06362746 \\
\text { porphyry }\end{array}$ & $\begin{array}{r}\text { LC1 } \\
004436 \\
910748 \\
06532793 \\
\text { chilled dol }\end{array}$ & $\begin{array}{r}\text { LC3 } \\
004438 \\
910749 \\
06532793 \\
\text { dolerite }\end{array}$ \\
\hline $\mathrm{SiO} 2(\mathrm{wt} \%)$ & 65.63 & 61.30 & 67.90 & 68.45 & 75.71 & 73.04 & 45.52 & 44.58 \\
\hline $\mathrm{TiO} 2$ & 0.60 & 0.79 & 0.57 & 0.48 & 0.09 & 0.20 & 2.89 & 2.61 \\
\hline $\mathrm{Al} 2 \mathrm{O} 3$ & 15.14 & 15.44 & 14.54 & 14.73 & 12.46 & 12.24 & 14.99 & 15.25 \\
\hline $\mathrm{Fe} 2 \mathrm{O} 3$ & 0.88 & 1.26 & 0.68 & 0.53 & 0.94 & 0.57 & 2.39 & 3.12 \\
\hline $\mathrm{FeO}$ & 3.22 & 4.80 & 3.16 & 2.78 & 0.46 & 1.32 & 10.13 & 8.88 \\
\hline $\mathrm{MnO}$ & 0.08 & 0.13 & 0.07 & 0.07 & 0.01 & 0.03 & 0.21 & 0.20 \\
\hline $\mathrm{MgO}$ & 2.46 & 4.01 & 2.04 & 1.71 & 0.06 & 0.20 & 7.05 & 7.25 \\
\hline $\mathrm{CaO}$ & 4.55 & 5.99 & 4.11 & 3.73 & 0.64 & 0.78 & 8.59 & 8.25 \\
\hline $\mathrm{Na} 2 \mathrm{O}$ & 3.54 & 3.68 & 2.89 & 2.96 & 3.19 & 2.90 & 3.79 & 3.60 \\
\hline $\mathrm{K} 2 \mathrm{O}$ & 3.24 & 1.80 & 3.06 & 3.54 & 5.92 & 5.17 & 1.24 & 0.98 \\
\hline $\mathrm{P} 2 \mathrm{O} 5$ & 0.17 & 0.19 & 0.13 & 0.12 & 0.00 & 0.04 & 0.86 & 0.76 \\
\hline $\mathrm{H} 2 \mathrm{O}+$ & 0.87 & 1.11 & 0.72 & 0.80 & 0.19 & 0.79 & 3.31 & 3.37 \\
\hline $\mathrm{CO} 2$ & 0.11 & 0.04 & 0.13 & 0.08 & 0.09 & 0.07 & 0.07 & 0.06 \\
\hline $\mathrm{SO} 3$ & 0.04 & 0.03 & 0.04 & 0.03 & 0.03 & 0.03 & 0.03 & 0.04 \\
\hline $\mathrm{FeS} 2$ & 0.00 & 0.00 & nd & nd & 0.00 & 0.00 & 0.01 & 0.00 \\
\hline TOTAL & 100.53 & 100.57 & 100.04 & 100.01 & 99.79 & 97.38 & 101.08 & 98.95 \\
\hline$S c(p p m)$ & $<9$ & 11 & 14 & 11 & $<9$ & $<9$ & 20 & 14 \\
\hline V & 90 & 115 & 80 & 65 & 8 & 18 & 290 & 250 \\
\hline Co & 8 & 14 & 12 & 10 & $<8$ & $<8$ & 50 & 58 \\
\hline $\mathrm{Ni}$ & 17 & 29 & 19 & 16 & 8 & 7 & 56 & 64 \\
\hline $\mathrm{Cu}$ & 16 & 11 & 12 & 7 & 13 & 13 & 30 & 25 \\
\hline $\mathrm{Zn}$ & 44 & 64 & 62 & 67 & 20 & 30 & 103 & 92 \\
\hline $\mathrm{Ga}$ & 15 & 17 & 18 & 18 & 21 & 18 & 19 & 21 \\
\hline As & $<20$ & $<20$ & $<20$ & $<20$ & $<20$ & $<20$ & $<20$ & $<20$ \\
\hline $\mathrm{Rb}$ & 142 & 138 & 145 & 170 & 320 & 333 & 76 & 64 \\
\hline Sr & 346 & 266 & 320 & 340 & 31 & 60 & 366 & 411 \\
\hline$Y$ & 20 & 30 & 25 & 22 & 60 & 57 & 47 & 40 \\
\hline $\mathrm{Zr}$ & 130 & 136 & 155 & 145 & 133 & 149 & 354 & 313 \\
\hline $\mathrm{Nb}$ & 3 & 6 & 10 & 9 & 11 & 8 & 11 & 9 \\
\hline Mo & $<5$ & $<5$ & $<5$ & 6 & $<5$ & $<5$ & $<5$ & $<5$ \\
\hline Sn & $<9$ & $<9$ & $<9$ & $<9$ & 9 & $<9$ & $<9$ & $<9$ \\
\hline $\mathrm{Ba}$ & 600 & 230 & 500 & 520 & 220 & 270 & 310 & 330 \\
\hline $\mathrm{La}$ & 42 & $<20$ & 44 & 35 & 72 & 52 & $<20$ & $<20$ \\
\hline $\mathrm{Ce}$ & 81 & 36 & 88 & 61 & 140 & 100 & 85 & 67 \\
\hline $\mathrm{Nd}$ & 44 & 43 & 32 & 21 & 98 & 68 & 64 & 60 \\
\hline$W$ & $<10$ & $<10$ & $<10$ & $<10$ & $<10$ & $<10$ & 11 & 11 \\
\hline $\mathrm{Pb}$ & 20 & $<10$ & 18 & 21 & 44 & 25 & $<10$ & $<10$ \\
\hline $\mathrm{Bi}$ & 6 & 6 & $<5$ & $<5$ & 5 & $<5$ & 8 & 7 \\
\hline Th & 26 & $<10$ & 31 & 21 & 43 & 39 & $<10$ & $<10$ \\
\hline $\mathrm{U}$ & 15 & $<10$ & $<10$ & $<10$ & 14 & 20 & $<10$ & $<10$ \\
\hline $\mathrm{FeOt}^{*}$ & 4.01 & 5.93 & 3.77 & 3.26 & 1.31 & 1.83 & 12.28 & 11.69 \\
\hline ASI & 0.860 & 0.817 & 0.936 & 0.951 & 0.972 & 1.039 & 0.646 & 0.694 \\
\hline $\mathrm{K} / \mathrm{Rb}$ & 189.4 & 108.3 & 175.2 & 172.9 & 153.6 & 128.9 & 135.4 & 127.1 \\
\hline
\end{tabular}

* $\mathrm{FeOt}$ is total iron expressed as FeO. ASI is alumina saturation index (molar $\mathrm{Al} 2 \mathrm{O} 3 /(\mathrm{CaO}+\mathrm{Na} 2 \mathrm{O}+\mathrm{K} 2 \mathrm{O}$ ).

$50 \mathrm{~mm}$ ), with needles ( $30 \mathrm{~mm}$ long) and angular clots of black tourmaline. Dyke margins are sharp, usually fairly straight, and intersect with sharp corners. In places, irregularities in opposite dyke walls can be matched (pl. 5). Locally the proportions of pink granite dykes and adamellite country rock are about equal, with the latter partly occurring as angular stoped blocks, from a few tens of millimetres to metres across, in the pink granite. These features indicate dilational emplacement, and suggest that the adamellite was solid and capable of brittle fracture at the time of emplacement of the pink granite dykes.

The tip of a small headland about $600 \mathrm{~m}$ south of Lagunta Creek is composed of pinkish, slightly porphyritic to seriate granite with minor biotite. Pink feldspar phenocrysts $(5-30 \mathrm{~mm})$ and equant quartz phenocrysts ( $\leq 5 \mathrm{~mm}$ ) both grade into the relatively coarse $(1-3 \mathrm{~mm}$ ) groundmass. This rock type appears to be a textural variant of the equigranular pink granite further north. To the 

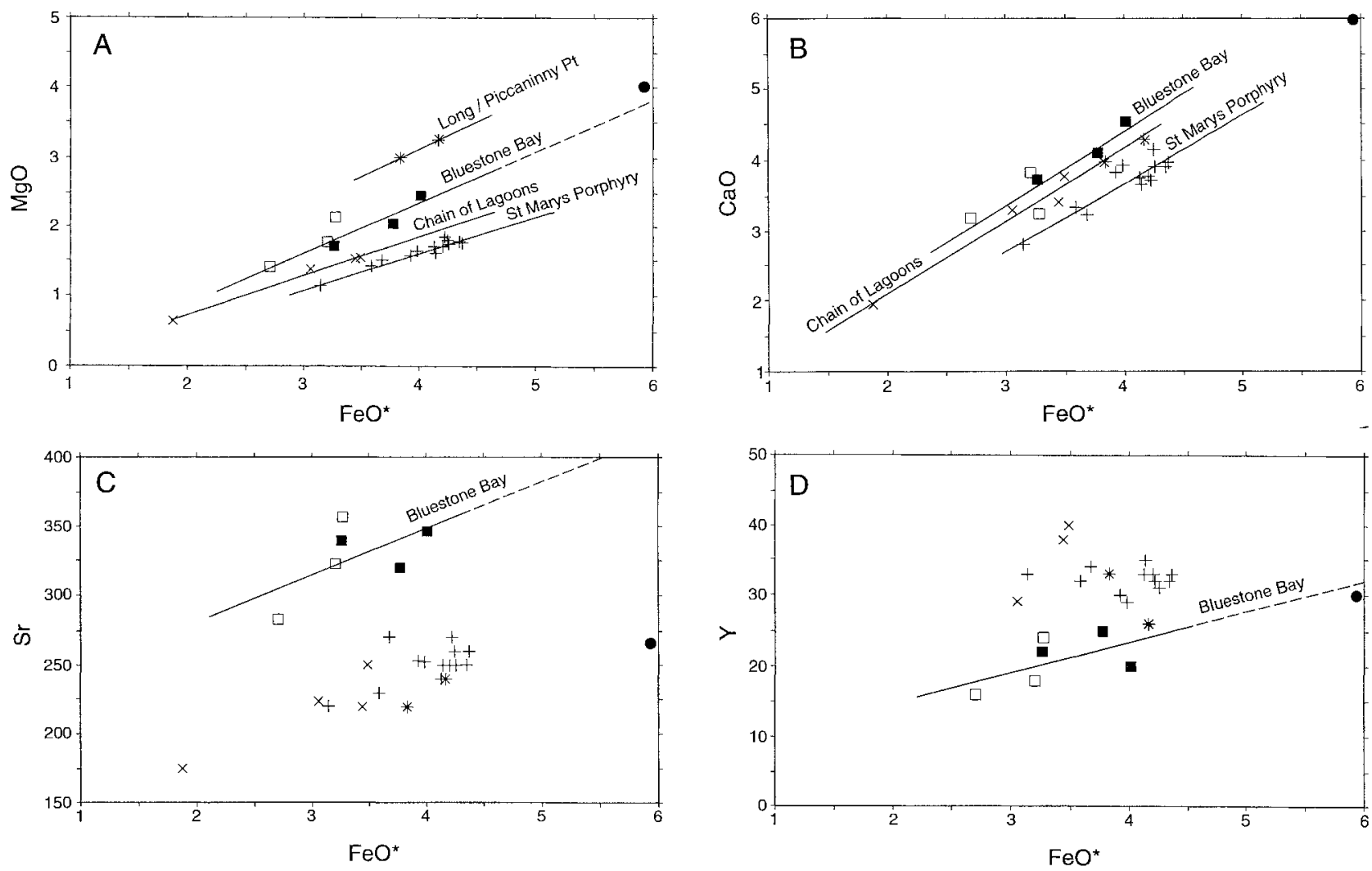

FIG. 4 - Selected two element variation diagrams for hornblende-bearing adamellitelgranodiorites from central eastern

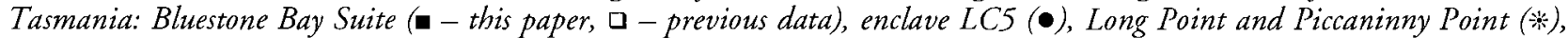
Chain of Lagoons (Piccaninny Creek) $(x)$ and St Marys Porphyry (+). Regression lines, where well-defined, are also shown. See text for further discussion and data sources. (A) MgO against total iron. (B) CaO against total iron. (C) Sr against total iron. (D) Y against total iron.

south of the headland, which is transected by a dyke-like body of distinctive granite porphyry (see below), there is an irregular contact against enclave-bearing adamellite which contains abundant dykes of pink granite and related pegmatitic and leucogranitic veins. A complex area of intensely veined adamellite and one or more small intrusions of similar pink seriate granite extends southward for $80 \mathrm{~m}$ to the northern end of the third sandy beach.

More outcrops of similar pink to brown, porphyritic to seriate, usually well-jointed felsic granite intrude adamellite near a headland $1 \mathrm{~km}$ from Lagunta Creek. Contacts are usually interfingering, with dykes and veins of pink leucocratic granite extending into and throughout the adamellite exposures.

Further south, adamellite is absent, and almost continuous coastal exposures of pink granite and its textural variants extend to Cooks Beach.

\section{Petrography}

A sample (LC7) from about $350 \mathrm{~m}$ south of Lagunta Creek consists of an allotriomorphicintergrowth of mainly anhedral quartz (1-3 mm), anhedral, turbid perthitic feldspar and anhedral to subhedral, turbid, weakly zoned plagioclase (probably largely albite). Mafic minerals are sparse $(<1 \%)$ and mainly comprise ragged flakes $(\leq 2.5 \mathrm{~mm}$ ) of biotite (a pale yellowish brown, $b$ and $c$ dark brown to nearly opaque) partly altered to chlorite, but there is also minor interstitial biotite with different pleochroism (a pale brownish yellow, $\mathrm{b}$ and $\mathrm{c}$ dark green). Accessory minerals include zircon and rounded to nearly square opaque grains $(0.15-0.8 \mathrm{~mm})$, which are larger and more abundant than in the adamellite. Slightly elongate euhedra $(<0.4 \mathrm{~mm})$ of an orange-brown material may be altered allanite.

Sample LC7 has a high magnetic susceptibility of about $5 \times 10^{-3} \mathrm{SI}$, suggesting that the opaque mineral is magnetite. This may be a local characteristic, as apparently similar pink to red granite outcrops at Coles Bay township, Cape Tourville lighthouse, the eastern headland of Bluestone Bay, and the southern end of Friendly Beaches gave very much lower values $\left(<0.1 \times 10^{-3} \mathrm{SI}\right)$.

\section{Geochemistry}

The rock (LC7) has a highly felsic, mildly metaluminous composition. Its pseudomode plots as alkali feldspar granite (fig. 3), since plagioclase is essentially albite. High Rb $(>250 \mathrm{ppm})$ and low $\mathrm{Sr}(<50 \mathrm{ppm})$ identify it as a fractionated granite, although $\mathrm{Ba}$ is a little higher than the suggested $200 \mathrm{ppm}$ limit. In addition to the metaluminous character, its negligible $\mathrm{P}_{2} \mathrm{O}_{5}$ and relatively high rare earth elements (REE), Th, $\mathrm{Y}^{2}$ and $\mathrm{Pb}$ are characteristic of fractionated I-types (Chappell \& White 1992). This is due to the low solubility of apatite in metaluminous melts, which results in the early removal of $\mathrm{P}_{2} \mathrm{O}_{5}$ from the liquid; thus monazite does not crystallise and REE and Th are concentrated in the liquid (e.g. Sawka et al. 1990). In felsic I-type granites, REE mostly occur in allanite (e.g. Bea 1996). 


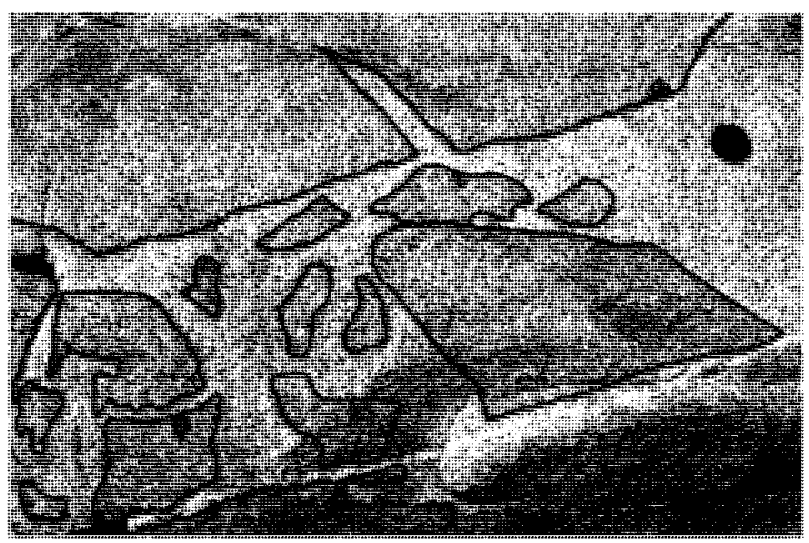

PLATE 4

Dilational intrusion of pink alkali feldspar granite, stoping blocks of grey adamellite, about $500 \mathrm{~m}$ south of Lagunta Creek. The contacts have been outlined for clarity. The diameter of the lens cap is $50 \mathrm{~mm}$.



PLATE 5

Close-up showing dilational intrusion of pink alkali feldspar granite into grey adamellite. Lens cap $50 \mathrm{~mm}$ diameter.

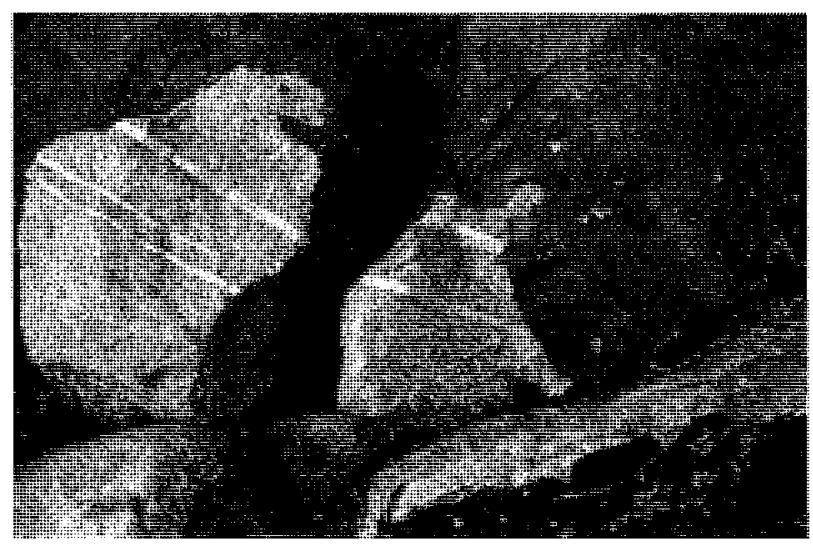

PLATE 6

Irregular contact of dolerite dyke, cross-cutting earlier veins of aplite veins within adamellite, near mouth of Lagunta Creek.

\section{Comparison with Other Eastern Tasmanian Granites}

More extensive sampling (data of B. W. Chappell and others, available in MRT "ROCKCHEM" database) shows that similar felsic fractionated I-type granite is widespread on Freycinet Peninsula and extends to the eastern part of Schouten Island. It is proposed to assign these granites to the Freycinet Suite.

The only other felsic fractionated I-type granites in the region are from the southern part of the Ben Lomond granite (Chappell \& White 1992; J.L. Everard, pers. obs.) and the Mt Stronach alkali feldspar granite of the Scottsdale Batholith (Robinson 1982, McClenaghan et al. 1982). The Ben Lomond granite in particular shows some similarities to the Freycinet Suite, such as high $\mathrm{Y}, \mathrm{Ce}$ and $\mathrm{Th}$ and low ASI and $\mathrm{P}_{2} \mathrm{O}_{5}$, but its spatial separation and slightly younger $\mathrm{Rb} / \mathrm{Sr}$ age (c. $362 \mathrm{Ma}$ adjusted for new decay constants, McDougall \& Leggo 1965) probably preclude a direct correlation. Granites of the Ile des Phoques, Maria Island and Deep Glen Bay (Clarke \& Baillie 1984, M.P. McClenaghan and J.L. Everard, pers. obs.) are, in contrast, felsic fractionated S-types.

\section{LEUCOGRANITE AND APLITE DYKES}

Dykes of off-white to very pale grey, aphanitic aplite are fairly common within the adamellite at Lagunta Creek. They are variable in width (typically $15-80 \mathrm{~mm}$ ) and locally pinch out. They have sharp contacts and locally truncate or dilationally transect the mafic enclaves, but terminate against the dolerite dyke (pl.6). This establishes an order of intrusion, and also indicates that the enclaves are older than, and not directly related to, the dolerite dyke. In one place a small fault, with a throw of about $45 \mathrm{~mm}$, offsets an aplite dyke.

On a small headland about $150 \mathrm{~m}$ south of Lagunta Creek, adamellite is cut by a $350-400 \mathrm{~mm}$ wide dyke of off-white to pale-grey, pale-pink to red weathering, porphyritic leucogranite. Small oblong phenocrysts of dull white (potassium?) feldspar $(5-20 \mathrm{~mm})$ and smaller $(\leq 5 \mathrm{~mm}$ ) equant quartz phenocrysts are somewhat sparsely scattered in a fine-grained leucocratic groundmass containing very little biotite. Contacts with the surrounding adamellite are sharp and slightly wavy to curved, and truncate enclaves within it. Thin irregular to curved aplite veins (a few millimetres to $10 \mathrm{~mm}$ wide) shoot off the leucogranite dyke for several metres into the adamellite, in places transecting enclaves without lateral displacement.

Further south, similar leucogranite and aplite can be seen to originate in the pink granite and occur as dykes and diffuse segregations within it. Thus, they belong to the same intrusive phase, which is younger than the adamellite.

\section{Petrography}

In thin section, a sample (LC8) of porphyritic leucogranite resembles the main pink granite. Phenocrysts of quartz are set in an allotriomorphic quartz-perthite intergrowth containing rare biotite (pleochroic from very dark brown to almost colourless) and substantial amounts of opaque accessory minerals (probably magnetite). Also like the pink granite, the hand specimen has a high magnetic susceptibility (about $4 \times 10^{-3} \mathrm{SI}$ ). 


\section{GRANITE PORPHYRY}

This rock type occurs at two localities. The northernmost occurrence is about $600 \mathrm{~m}$ south of Lagunta Creek, where a north-south trending body, possibly a dyke about $15 \mathrm{~m}$ wide, is exposed over a strike distance of about $35 \mathrm{~m}$ on a small headland.

The rock is a dark-grey, reddish-brown to pink weathering, visually striking porphyritic granite, containing very abundant phenocrysts of feldspar (10-40 mm long) and globular quartz $(\leq 5 \mathrm{~mm})$, together with small clots of biotite (to $3 \mathrm{~mm}$ ) in a grey fine-grained leucocratic groundmass. There is a preferred direction of alignment of the feldspar phenocrysts at an azimuth of about $10^{\circ}$, approximately parallel to the strike of the body. No enclaves, dykes or veins are present.

Enclave-bearing adamellite, veined by pink leucogranite, lies on the eastern side of the porphyry, but the contact is obscured beneath beach boulders (of mainly granite porphyry) on the shore, and soil behind the headland. At the northern end of the "dyke", the western contact with a pinkish, less porphyritic to seriate granite trends at about $170^{\circ}$ to $190^{\circ}$ but is locally slightly wavy to irregular. About $25 \mathrm{~m}$ to the south, on the south side of the headland and west of the porphyry, a small (less than $10 \times 10 \mathrm{~m}$ ) body of grey enclave-bearing adamellite is intensely veined by pink leucocratic granite offshoots of the seriate granite to the north. Thus, the porphyry may be later than, although possibly related to, the pink seriate granite.

Similar granite porphyry occurs $800-900 \mathrm{~m}$ south of Lagunta Creek at the southern end of the third sandy beach. Here grey adamellite occurs behind the beach to the northeast; the contact probably strikes at about $170^{\circ}$ and is subvertical or dips very steeply to the west. The porphyry has a grey chilled margin $20-50 \mathrm{~mm}$ wide, against (to the east) a pink microgranite about $100 \mathrm{~mm}$ wide; sand obscures the actual contact with adamellite $1.5 \mathrm{~m}$ further east. These relationships are consistent with the porphyry being younger than the adamellite. About $40 \mathrm{~m}$ southwest of this locality, the porphyry body passes southward to a small, poorly exposed outcrop of adamellite. Here the contact is obscured, but possibly strikes at about $135^{\circ}$.

\section{Petrography}

In a thin section of granite porphyry (sample LC6), the quartz phenocrysts are clear, rounded euhedra and slightly embayed subhedra, whilst both potassium feldspar and sodic plagioclase phenocrysts are turbid and euhedral. The latter contain numerous small inclusions of secondary white mica. Biotite ( $\alpha$ pale brownish yellow, $\beta$ and $\chi$ dark green) occurs as small euhedral to ragged phenocrysts, irregular clots and as inclusions in quartz and feldspar phenocrysts. It is, therefore, an early crystallising mineral, although now partly altered to chlorite and muscovite. Zircon, monazite and opaque grains are abundant as inclusions within biotite. The groundmass consists of fine-grained $(0.02-0.05 \mathrm{~mm})$ quartz and feldspar, with subordinate splinters of partly altered biotite.

The hand specimen is essentially non-magnetic (susceptibility about $0.1 \times 10^{-3} \mathrm{SI}$ ).

\section{Geochemistry}

The granite porphyry is not quite as felsic as the pink granite $\mathrm{LC} 7$ (lower $\mathrm{SiO}_{2}$, higher total $\mathrm{FeO}, \mathrm{TiO}_{2}, \mathrm{MgO}$ and $\mathrm{CaO}$ ), and the pseudomode plots as granite (sensu stricto) (fig. 3). Although $\mathrm{Rb}$ is slightly higher, so are $\mathrm{Sr}$ and $\mathrm{Ba}$, and the rock is probably less fractionated. This is consistent with lower to slightly lower $\mathrm{REE}, \mathrm{Y}$, Th and $\mathrm{Pb}$, and higher (but still very low) $\mathrm{P}_{2} \mathrm{O}_{5}$. Although weakly peraluminous, there is little doubt that this rock is also an I-type.

\section{DOLERITE DYKE}

Near the mouth of Lagunta Creek, a conspicuous black dolerite dyke intrudes the grey adamellite (pl. 1). At its northern end, where it disappears beneath sand at the southern end of Hazards Beach, it is about $6.5 \mathrm{~m}$ wide. It can be followed southward (trending at about $165^{\circ}$ ) diagonally across the shore platform for about $70 \mathrm{~m}$ until it disappears due to poor inland exposure.

Dyke margins are chilled for about $50 \mathrm{~mm}$ from the contacts, but the adjacent adamellite is uniform in appearance right up to the contact and appears unaffected by the dolerite. The central part of the dyke has a grain size of typically $0.5-1 \mathrm{~mm}$ but is locally coarser-grained and very feldspathic, with plagioclase laths $1-3 \mathrm{~mm}$ long grading up to a few microphenocrysts $5-10 \mathrm{~mm}$ long and larger, in a sea-green weathering mesostasis. Sporadic $(<1 \%$ by volume) but large and conspicuous plagioclase megacrysts (pl. 7), typically measuring $10-30 \times 5-20 \mathrm{~mm}$ but up to $140 \times 50 \mathrm{~mm}$, are more common in the northern part of the dyke, and in its centre rather than near its margins. They are mostly oblong to rhomboid euhedra and subhedra with rounded corners, and are off-white to pale pink, sometimes with clear cores, or clear throughout.

The eastern (landward) contact of the dyke is sharp and exposed continuously for $9 \mathrm{~m}$, and intermittently for a further $18 \mathrm{~m}$. It strikes at $165^{\circ}$ and dips at $75^{\circ}$ to $85^{\circ}$ to the east but is locally irregular. At some irregularities, fingers and offshoots of dolerite (one $130 \mathrm{~mm}$ long) extend into the adamellite.

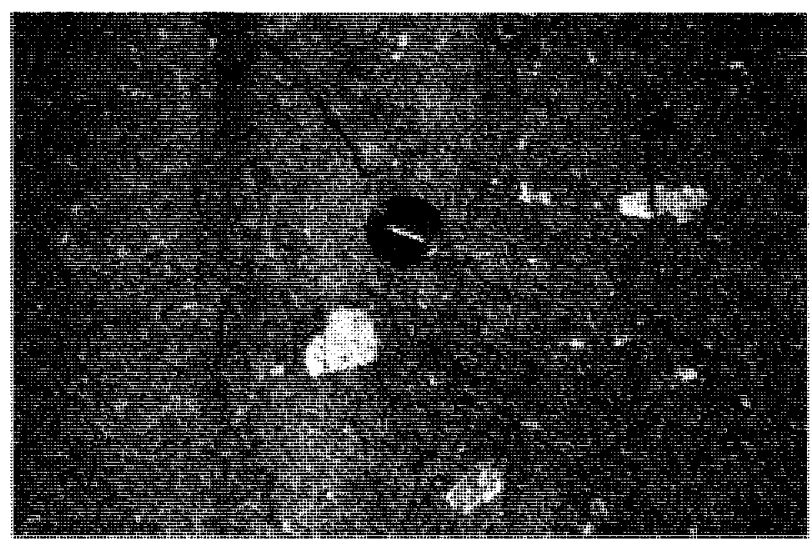

PLATE 7

Close up of dolerite dyke showing plagioclase megacrysts. Lens cap $50 \mathrm{~mm}$ diameter. 
The western (seaward) contact is better exposed, nearly completely so for the most northern $35 \mathrm{~m}$ of the dyke. It has a similar overall trend and steep generally eastward dip but is more irregular than the eastern contact. Although always sharp, the contact varies from locally straight (on a scale of a few millimetres) for up to a metre or more with abrupt changes in direction, to elsewhere highly irregular. In several places, it is clearly controlled by jointing within the host adamellite.

At several places near the western contact, irregularly shaped, angular-stoped blocks of adamellite up to $0.5 \mathrm{~m}$ long occur within the dolerite. In some cases, their shape can clearly be matched with irregularities in the adjacent wall of the dyke, indicating dilational emplacement.

Both contacts, but especially the western one, show a tendency to step abruptly eastward as one follows them to the north (i.e. dextrally). At each of two such places near the northern end of the western contact, a finger of dolerite, initially about $0.5 \mathrm{~m}$ wide, shoots off northward for several metres into the adamellite (pl. 8). The two fingers are subparallel and linked by narrow cross-dykes. Each finger gradually narrows northward and tapers away, but the trends continue as joints within the adamellite. About $7 \mathrm{~m}$ west of the main dyke, another narrow ( $70-150 \mathrm{~mm}$ wide) dyke occurs within the adamellite. Its strike is irregular, and to the south it trends at about $150^{\circ}$ towards the main dyke, which it probably joins beneath soil cover.

In several places, the contacts of the dolerite dyke abruptly crosscut mafic enclaves within the host adamellite. Aplite and leucogranite veins are also abruptly truncated against the contact (pl. 6), and nowhere are found within the dolerite, indicating that the latter is younger.

The sharp angular contacts of the dyke, their control by jointing in the host, the chilled margins and the stoped blocks suggest that the adamellite had already essentially cooled and solidified at the time of dyke emplacement.

\section{Petrography}

A sample (LC3) from the centre of the dyke consists of a subophitic intergrowth of weakly zoned, pinkish titanaugite granules $(\leq 1 \mathrm{~mm})$, turbid plagioclase and ragged opaques (magnetite?), together with scattered equant pseudomorphs of former olivine ( $\leq 0.8 \mathrm{~mm}$ across), now replaced by finegrained, colourless and nearly isotropic serpentine and magnetite dust. Secondary chlorite, epidote and actinolite are also present. Some large $(1 \mathrm{~mm})$ crystals of a mineral (probably titanite) with very high relief and birefringence are later than plagioclase. The plagioclase megacrysts are difficult to extract, but a chip gave an electron microprobe analysis of $\mathrm{An}_{64.5} \mathrm{Ab}_{34.1} \mathrm{Or}_{1.4}$ (calcic labradorite).

The chilled margin (sample LC1) is mineralogically similar. Laths of plagioclase $(\leq 0.3 \mathrm{~mm}$ long) grade down to an intergranular groundmass of plagioclase, titanaugite granules and generally elongate opaques ( $\leq 0.05 \mathrm{~mm}$ long), together with secondary chlorite and actinolite. Minute fragments of a brown pleochroic mineral (probably biotite) are closely associated with chlorite. Abundant amygdales $(\leq 0.5 \mathrm{~mm}$ ) are filled with strongly pleochroic (yellow to green) chlorite with anomalous blue to purple birefringence.

These samples have a high magnetic susceptibility (23$25 \times 10^{-3} \mathrm{SI}$ ), consistent with the presence of abundant magnetite.



PLATE 8

Offshoot of dolerite dyke from western contact, intruding along joints in adamellite, near mouth of Lagunta Creek. The hammer is $400 \mathrm{~mm}$ long.

\section{Geochemistry}

There is little difference between analyses (table 1) of the chilled margin (LCl) and the central part of the dyke (LC3). The dolerite has an alkalic major element chemistry, and is normatively a hawaiite (ne $<5 \%$; plagioclase normatively andesine). Low $\mathrm{MgO}, \mathrm{Mg} \#\left(54.7\right.$ and 56.7 at $\mathrm{Fe}_{2} \mathrm{O}_{3} / \mathrm{FeO}=$ 0.20 ) and $\mathrm{Ni}$ indicate that the dolerite is not an unmodified partial melt of primitive mantle, but has undergone olivine \pm pyroxene fractionation. Other notable features of the major element chemistry are rather high $\mathrm{Al}_{2} \mathrm{O}_{3}$ (consistent with the presence of probably cognate plagioclase megacrysts, the likely crustal liquidus phase) and rather high $\mathrm{TiO}_{2}$.

The main features of the incompatible trace element geochemistry are very low $\mathrm{Nb}$ (especially for an undersaturated rock with alkalic major element chemistry), low Sr, high $\mathrm{Y}$ and low $\mathrm{K} / \mathrm{Rb}$. This is clearly seen in a primitive mantle normalised spider diagram of available trace elements (fig. 5), which displays negative $\mathrm{Nb}$ and $\mathrm{Sr}$ anomalies relative to adjacent elements of similar incompatibility. Whilst low $\mathrm{Sr}$ may simply reflect fractionation of plagioclase, $\mathrm{Nb}$ is unlikely to have been depleted by either fractionation or alteration. By comparison, the average chilled margin of Tasmanian Jurassic dolerite (Hergt et al. 1989) is much lower in $\mathrm{TiO}_{2}$, $\mathrm{P}_{2} \mathrm{O}_{5}, \mathrm{Zr}$ and $\mathrm{Nd}$, whilst Triassic hawaiite from near $\mathrm{St}$ Marys (Everard 1987) lacks a negative Nb anomaly.

The dolerite dyke may be part of a large swarm that is widespread in northeast Tasmania, but best developed in the Blue Tier-Great Musselroe River area (e.g. McClenaghan \& Williams 1983). However, similar dolerite dykes occur from south Maria Island (microdiorite of Clarke \& Baillie 1984) to at least the northern tip of Flinders Island (J.L. Everard, pers. obs.). Their geochemistry (e.g. McClenaghan et al. 1982, 1992, McClenaghan 1984, Baillie 1986, MRT ROCKCHEM database) is highly variable, ranging from basaltic to andesitic $\left(\mathrm{SiO}_{2} 46-60 \%\right)$ and from tholeiitic and weakly alkaline. They pre-date the Late Carboniferous to Middle Triassic Parmeener Super-group but intrude both the Ordovician-Early Devonian Mathinna Group and the Middle-Late Devonian granites. However, one tholeiitic dyke at Lady Barron, Flinders Island is transected by quartz feldspar porphyry, suggesting at least locally a syn-granitic Devonian age (Baillie 1986: 29). 




FIG. 5 - Primitive mantle normalised incompatible element spider diagram (after Sun \& McDonough 1989), for dolerite dyke at Lagunta Creek (samples LC1, LC3). Average chilled margin of Tasmanian Jurassic dolerite (Hergt et al. 1989) and Triassic basalt (M250) at St Marys (Everard 1987) also plotted for comparison.
The Lagunta Creek dyke, which is younger than one of the youngest eastern Tasmanian granites (c. $373 \mathrm{Ma}$ ), is the one of the most mafic (the lowest $\mathrm{SiO}_{2}$ ) and most alkaline (high $\mathrm{Na}_{2} \mathrm{O}+\mathrm{K}_{2} \mathrm{O}$ ) representatives yet analysed. Trace element data for other dykes are limited (especially for rare earth elements) but two dykes from the Pyengana area also display negative $\mathrm{Nb}$ anomalies (relative to $\mathrm{K}, \mathrm{Ba}$ and $\mathrm{Ce}$ ) on mantle-normalised spider diagrams (J.L. Everard, pers. obs.).

Soesoo \& Nicholls (1999) have reported similar negative $\mathrm{Nb}$ anomalies from certain mafic rocks associated with Devonian Lachlan Fold Belt granites in eastern Victoria, and suggested, by analogy with modern volcanic rocks, a subduction-related, island arc or continental margin tectonic setting for them. Alternatively, it could be a crustal signature, indicating either a component derived by direct melting of continental crust (cf. Morris et al. 2000), or indirect contamination of the mantle source by subducted pelagic sediments (cf. Hergt et al. 1989).

\section{DISCUSSION AND CONCLUSIONS}

The similarity of the grey enclave-bearing hornblende adamellite at Lagunta Creek to the body exposed $3 \mathrm{~km}$ to the north at Wineglass Bay suggests that they are part of the same pluton. More adamellite occurs $5 \mathrm{~km}$ to the northwest, between Sleepy Bay and Bluestone Bay (fig. 1). These adamellites appear to belong to the distinctive Bluestone Bay Suite and, although the oldest granites in the district, are dissimilar to and younger than other I-type granodiorite/ adamellite intrusions of the Blue Tier Batholith.

A contact, accompanied by numerous quartz veins, with an altered pink granite is exposed on the headland (FP105345) between Sleepy Bay and Carp Bay. At Bluestone Bay, the eastern headland comprises pink finegrained to pegmatitic felsic granite, whereas to the northwest there is more enclave-bearing grey adamellite/granodiorite. At each of these localities, as at Coles Bay (Groves 1965) and Lagunta Creek, the adamellites are intruded by pink granite, or by aplite and leucogranite dykes related to it. This uniform order of intrusion throughout the district is consistent with the $\mathrm{Rb} / \mathrm{Sr}$ isotopic ages. The now disjunct bodies of hornblende adamellite are probably eroded remnants of a roof pendant that was intruded from below by younger pink granite, a felsic fractionated I-type. The coastal section south of Lagunta Creek, in particular, appears to represent a thin roof pendant of adamellite, intensely intruded and stoped by the pink granite. Some of the smaller adamellite bodies may be disconnected rafts.

Chappell et al. (1991) listed the Coles Bay, Hazards, Freycinet (south of the Hazards isthmus) and Schouten granites as separate felsic I-type plutons, whilst a small body at Bluestone Bay was considered to be an unfractionated mafic I-type. However, all the felsic bodies (Freycinet Suite) are chemically similar, although the Hazards body is the most fractionated (Chappell \& White 1992). Furthermore, granite bedrock is probably continuous below sea level beneath both the Hazards isthmus and Schouten Passage. Concealed screens of country rock are unlikely to be present, as elsewhere in eastern Tasmania hornfelsed Mathinna Group is commonly a resistant, topographically prominent lithology.

The later dolerite dyke at Lagunta Creek is a fractionated hawaiite with an unusual crustal and/or subduction-related trace element signature. Further work on other graniteassociated mafic rocks in eastern Tasmania and elsewhere is necessary to evaluate its significance. However, it may represent the late escape of a small, evolved volume of mantle-derived magma that previously underplated the lower crust and induced partial melting to generate the "infracrustal" I-type granites.

Partial melting of lower continental crust by the intrusion of, or crustal underplating by, mantle-derived mafic magmas has been assigned an important role in granite petrogenesis, based on both field observations in Tasmania (McClenaghan 1984) and elsewhere in the Lachlan Fold Belt (e.g. Soesoo $\&$ Nicholls 1999) and on theoretical grounds (e.g. Huppert \& Sparks 1988). However the possibility and nature of a mantle-derived chemical component in the granites themselves remains controversial (cf. Collins 1998 vs Chappell 1996, Chappell et al. 1999, and references therein). 


\section{ACKNOWLEDGEMENTS}

The assistance of past and present staff at the Tasmania Department of Mines (now Mineral Resources Tasmania) is gratefully acknowledged. The National Parks and Wildlife Service kindly granted a sample permit. The comments of two anonymous reviewers greatly assisted in improving this paper.

\section{REFERENCES}

Bacon, C.A. \& CorbetT, K.D., 1984: The Schouten Island coalfield. Unpubl. rep. Tasm. Dep. Mines 1984/37.

BaIllie, P.W., 1986: EDDYSTONE. Geol. Atlas 1:50 000 series. Geol. Surv. explan. rep. Sheet 25 (8516S). Department of Mines, Tasmania.

BEA, F., 1996: Residence of REE, Y, Th and U in granites and crustal protoliths: implications for the chemistry of crustal melts. J. Petrol. 37: 521-552.

Chappell, B.W., 1996: Magma mixing and the production of chemical variation within granite suites: evidence from the granites of southeastern Australia. J. Petrol. 37: 449470 .

Chappell, B.W. \& White, A.J.R., 1992: I- and S- type granites in the Lachlan Fold Belt. Trans. R. Soc. Edinburgh (Earth Sci.) 83: 1-26.

Chappell, B.W., English, P.M., King, P. L., White, A.J.R. \& WyBorN, D., 1991: Granites and related rocks of the Lachlan Fold Belt (1:2 500000 scale map). Bureau of Mineral Resources, Geology and Geophysics, Canberra.

Chappell, B.W., White, A.J.R., Williams, I.S., Wyborn, D., HERGT, J.M. \& WOODHEAD, J.D., 1999: Discussion and reply: Evaluation of petrogenetic models for Lachlan Fold Belt granitoids: implications for crustal architecture and tectonic models. Aust. J. Earth Sci. 46: 827-836.

Chen, Y.D., Price, R. C. \& White, A.J.R., 1989: Inclusions in three $\mathrm{S}$-type granites from southeastern Australia. J. Petrol. 30: 1181-1138.

Clarke, M.J. \& Baillie, P.W., 1984: MARIA. Geol. Atlas I:50 000 series. Geol. Surv. explan. rep. Sheet 77 (8512N). Department of Mines, Tasmania.

Cocker, J.D., 1977: Petrogenesis of the Tasmanian granitoids. Unpubl. PhD thesis, Univ. Tasm.

Collins, W.J., 1998: Evaluation of petrogenetic models for Lachlan Fold Belt granitoids: implications for crustal architecture and tectonic models. Aust. J. Earth Sci. 45 . 483-500.

Dunderdale, C., 1989: The granitoids of the Hazards Range, eastern central Tasmania: conditions of emplacement and alteration. Unpubl. BSc thesis, Univ. St Andrews (Scotland).

EVERARD, J.L., 1987: Petrology of the Triassic basalt. In Turner, N.J. \& Calver, C.R. (Eds): ST MARYS. Geol. Atlas 1:50 000 series. Geol. Surv. explan. rep. Sheet $49(8514 \mathrm{~N})$. Department of Mines, Tasmania.: 89-121.

FLOOD, R.H. \& SHAW, S.E., 1995: Granites and microgranitoid enclaves: the importance of cumulates (abs.). In Brown, M. \& Piccoli, P.M. (Eds): THE ORIGIN OF GRANITES AND RELATED ROCKS. Third Hutton Symposium, College Park, Maryland. U.S. Geological Survey Circular 1129.

Forsyth, S.M., Clarke, M.J., Calver, C.R., McClenaghan, M.P. \& CORBETT, K.D. (comp.), 1995: GEOLOGY OF SOUTHEAST TASMANIA. Geol. Atlas 1:250 000 digital series. Tasmanian Geological Survey.

Groves, D.I., 1965: Granites of the Coles Bay area. Tech. Rep. Dep. Mines, Tasm. 10: 64-71.

Hergt, J.M., Chappell, B.W., McCulloch, M. T., McDougall. I. \& Chivas, A.R., 1989: Geochemical and isotopic constraints on the origin of the Jurassic dolerites of Tasmania. J. Petrol. 30: 841-883.

HupPert, H.E. \& SparKS, R.S.J., 1988: The generation of granitic magmas by intrusion of basalt into continental crust. $J$. Petrol. 28(3): 599-624.

IsHIHARA, S., 1977: The magnetite- series and ilmenite- series granitic rocks. Min. Geol. 27: 293-305.

MCClentaghan, M.P., 1984: The petrology, mineralogy and geochemistry of the Pyengana and Gardens granodiorites, the Hogans Road diorite and the dolerite dykes of the Blue Tier Batholith. Unpubl. Rep. Tasm. Dep. Mines $1984 / 04$.

McClenaghan, M.P. \& Williams, P.W., 1983: BLUE TIER. Geol. Atlas 1:50 000 series. Geol. Surv. explan. rep. Sheet 33 (8515N). Department of Mines, Tasmania.

McClenaghan, M.P., Turner, N.J., Baillie, P.W., Brown, A.V., WILliams, P.R. \& Moore, W.R., 1982: Geology of the Ringarooma-Boobyalla area. Geol. Surv. Bull. 61 . Department of Mines, Tasmania.

McClenaghan, M.P., Turner, N.J. \& Everard, J.L., 1992: ST HELENS. Geol. Atlas 1:50 000 series. Geol. Surv. explan. rep. Sheet 41 (8515S). Department of Mines, Tasmania.

McDougALl, I. \& LeGGo, P.J., 1965: Isotopic age determination on granitic rocks from Tasmania. J. Geol. Soc. Aust. 12: 295-332.

Morris, G.A., Larson, P.B. $\&$ HoOPER, P.R., 2000: 'Subduction style' magmatism in a non-subduction setting: the Colville Igneous Complex, NE Washington State, USA. J. Petrol. 41: 43-67.

Reid, J.B., Evans, O.C. \& Fates, D.G., 1983: Magma mixing in granitic rocks of the central Sierra Nevada, California. Earth Planet. Sci. Lett. 66: 243-261.

Robinson, K.P., 1982: The geology and geochemistry of the Mt Stronach Region, Scottsdale. Unpubl. BSc Hons. thesis, Univ. Tasm.

Sawka, W.N., Heizler, M.T., Kistler, R.W. \& Chappell, B.W., 1990: Geochemistry of highly fractionated I- and S-type granites from the tin-tungsten province of western Tasmania. In Hannah, H.J. \& Stein, J.L. (Eds): OREBEARING GRANITE SYSTEMS: PETROGENESIS AND MINERALIZING PROCESSES. Geological Society of America Special Paper 246.

SOESOO, A. \& NichoLLS, I., 1999: Mafic rocks spatially associated with Devonian felsic intrusions of the southern Lachlan Fold Belt: a possible mantle contribution to crustal evolution processes. Aust. J. Earth Sci. 46: 725-734.

STreckeisen, A.L., 1973: Plutonic rocks. Classification and nomenclature recommended by the IUGS subcommission on the systematics of igneous rocks. Geotimes 18(10): 26-30.

Sun, S.-S. \& McDonough, W.F., 1989: Chemical and isotopic systematics of oceanic basalts: implications for mantle composition and processes; In Saunders, A.D. \& Norry, M.J. (Eds): MAGMATISM IN THE OCEAN BASINS. Geol. Soc. London Spec. Publ. 42: 313-346.

Turner, N.J. \& Calver, CR., 1987: ST MARYS. Geol. Atlas 1:50 000 series. Geol. Surv. explan. rep. Sheet $49(8514 \mathrm{~N})$. Department of Mines, Tasmania.

Turner, N.J., Black, L.P. \& Higgins, N.C., 1986: The St Marys Porphyrite and related dykes: a Devonian intracaldera ignimbrite and its feeder. Aust. J. Earth Sci. 33: 201-218.

VERNON, R.H., 1984: Microgranitoid enclaves: Globules of a hybrid magma quenched in a plutonic environment. Nature 304: 438-439.

White, A.J.R. \& Chappell, B.W., 1977: Ultrametamorphism and granitoid genesis. Tectonophysics 43: 7-22.

(accepted 25 June 2001) 